\title{
Pengenalan Pola Angka Menggunakan Pendekatan Optimisasi Sistem Kekebalan Buatan (Artificial Immune System)
}

\author{
Anggari Ayu Prahartiningsyah", Tri Basuki Kurniawan \\ Program Pascasarjana, Program Studi Teknik Informatika, Universitas Bina Darma, Palembang, Indonesia \\ Email: ${ }^{1}$ anggari.ayu @gmail.com, ${ }^{2}$ tribasukikurniawan@ binadarma.ac.id \\ Email Penulis Korespondensi: anggari.ayu@gmail.com
}

\begin{abstract}
Abstrak-Pemilihan umum di Indonesia sendiri masih mengalami masalah teknis dan non teknis dimana masalah teknis tersebut terjadi pada rekapitulasi suara dari lembar $\mathrm{C} 1$ yang masih salah input dan dikerjakan secara manual. Masalah terjadi pada perbedaan data C1 yang diunggah dan data di Situng KPU serta lembar C1 yang diunggah buram, tidak jelas, lembar C1 yang tercoret atau terlipat dalam Situng KPU. Tujuan penelitian ini adalah mengurangi kesalahan pada input data dan mengubah pekerjaan yang dikerjakan secara manual ke sistem, membuat sistem pengenalan pola angka menggunakan pendekatan optimisasi sistem kekebalan buatan (Artificial Immune System), menguji dan menganalisis kerja sistem dengan memperhitungkan tingkat akurasi, ketelitian dan kecepatan dalam mengenali pola angka. Sistem yang dibuat menerapkan pendekatan optimisasi sistem kekebalan buatan Artificial Immune System dengan metode Randomized Real-Valued Negative Selection Algorithm. Hasil penelitian ini didapat akurasi dari proses testing 85.85715728861501 dengan eror testing 0.14142842711384984
\end{abstract}

Kata Kunci: Sistem Kekebalan Buatan; Randomized Real; Valued Negative Selection Algorithm.

Abstract-The general election in Indonesia itself still experiences technical and non-technical problems where the technical problems occur in the recapitulation of votes from $\mathrm{C} 1$ sheet which are still incorrectly inputted and done manually. The problem occurred with the difference in the uploaded C1 data and the data in the Situng KPU and the C1 sheet uploaded was blurry, unclear, C1 sheet which was crossed out or folded in the Situng KPU. The purpose of this research is to reduce errors in data input and change the work that is done manually to the system, create a number pattern recognition system using an Artificial Immune System optimization approach, test and analyze the work of the system by taking into account the level of accuracy, preciseness and speed in recognize number patterns. The system created to applies an artificial immune system optimization approach with the Artificial Immune System using the Randomized Real-Valued Negative Selection Algorithm. The results of this study obtained the accuracy of the testing process 85.85715728861501 with a testing error of 0.14142842711384984 .

Keywords: Artificial Immune System; Randomized Real-Valued Negative Selection Algorithm

\section{PENDAHULUAN}

Kecerdasan buatan (Artificial Intelligence) telah dipelajari bertahun-tahun oleh para filsuf. Hal ini membuat Artificial Intelligence (AI) berusaha membangun entitas-entitas cerdas yang sesuai dengan pemahaman manusia. Kecerdasan buatan merupakan cabang dari ilmu komputer yang mencakup bidang ilmu yang cukup besar, salah satunya adalah pattern recognition dan machine learning.

Machine learning adalah sebuah metode yang digunakan untuk membuat program yang bisa belajar dari data. Dimana machine learning merupakan implementasi dari AI [1]. Machine learning sendiri berfokus pada pengembangan program-program komputer yang dapat mengajarkan dirinya sendiri untuk tumbuh dan berubah bila diberikan data baru. Proses machine learning sama seperti data mining yaitu, belajar melalui data untuk mencari pola dan belajar bekerja dengan cara menemukan beberapa hubungan antara fitur dan variabel target lalu diuji dengan satu set pelatihan data (training set) dan dataset yang terpisah (test set). Pada machine learning terdapat berbagai algoritma, salah satunya adalah Sistem Kekebalan Buatan (Artificial Immune System).

Artificial Immune System (AIS) merupakan sistem komputasi yang diinspirasikan oleh teori imunologi, mengamati fungsi, prinsip dan mekanisme kekebalan yang diaplikasikan dalam pemecahan masalah. AIS telah digunakan dalam menyelesaikan berbagai bidang seperti optimasi, klasifikasi, clustering, deteksi anomali, machine learning, adaptive control, dan associative memories [2].

Sedangkan Pengenalan pola (pattern recognition) adalah sebuah proses untuk mengambil dan mengklasifikasi data, dimana data tersebut dapat berupa gambar, tulisan, suara, angka dan lain-lain. Pengenalan pola merupakan salah satu bidang dalam pembelajaran mesin (machine learning) yang menitikberatkan pada metode klasifikasi objek ke dalam kelas-kelas tertentu untuk menyelesaikan masalah tertentu. Pengenalan pola telah dilakukan pada berbagai jenis data dimana setiap jenis data memiliki karakteristik tersendiri. Pengenalan pola juga dapat digunakan untuk menyelesaikan masalah dalam penetapan dan hasil pemilihan umum di Komisi Pemilihan Umum (KPU).

Pada pemilihan umum di Indonesia sendiri masih mengalami masalah teknis dan non teknis, dimana masalah teknis tersebut terjadi pada rekapitulasi suara dari lembar $\mathrm{C} 1$ yang masih salah input dan dikerjakan secara manual [3]. Masalah tersebut biasanya terjadi di tingkat kecamatan, dimana rekapitulasi pada tingkat tersebut memakan waktu yang lama. Hal ini karena adanya perbedaan pendapat atau selisih angka yang ada di lembar $\mathrm{C} 1$ yang harus dicocokkan kembali, diverifikasi, adu data dan dikoreksi. Selain itu, format baru pada pemilu 2019 dengan pemilu-pemilu sebelumnya juga berpengaruh. Dimana pada pemilu 2019 hasil perhitungan suara di TPS langsung diteruskan ke kecamatan. Selain masalah yang terjadi di tingkat kecamatan juga terjadi masalah pada 
perbedaan data C1 yang diunggah dan data di Sistem Informasi Penghitungan Suara (Situng) KPU. Lalu lembar $\mathrm{C} 1$ yang diunggah buram, tidak jelas, lembar C1 yang tercoret atau terlipat dalam Situng KPU.

Pada penelitian yang berjudul "The Immune System as a Model for Pattern Recognition and Classification", hasil pengenalan dengan menggunakan SHA (Simple Highest Avidity) berkisar 63,2 \% hingga 96\%. Hasil rata-rata klasifikasi untuk semua proses adalah $83,2 \%$. Sedangkan hasil pengenalan dengan menggunakan RHA (Relative Highest Avidity) yaitu 83,2\% dan diberi label "Too Close To Determine" dan klasifikasinya tidak dilanjutkan. Sisanya, 85,5 \% diklasifikasikan dengan benar. Ketika dataset kedua disajikan, hasil klasifikasi menggunakan SHA menjadi 73,5\% dan hasil menggunakan RHA menjadi 80,3\% [4].

Pada penelitian "A Negative Selection Algorithm For Classification And Reduction Of The Noise Effect", menunjukkan bahwa negative selection algorithm berguna untuk klasifikasi jika digabungkan dengan mekanisme lain, seperti seleksi klonal. Kombinasi ini memungkinkan ANSC (Artificial Negative Selection Classifier) untuk memecahkan tiga masalah yang mencegah algoritma seleksi negatif diterapkan pada masalah klasifikasi. Pertama, ANSC menggunakan CLONALG dengan algoritma seleksi negatif sehingga pencariannya tidak acak. Kedua, metode pemotongan dapat mengurangi noise effect, sehingga mengurangi bahaya overfitting. Ketiga, setiap ALC (Artificial Lymphocytes) diperoleh dengan menggunakan sampel dari semua kelas, sehingga ANSC dapat mengklasifikasikan data dalam multi-class classification [5].

Pada penelitian "Analisa Performa Pengenalan Tulisan Tangan Angka Berdasarkan Jumlah Iterasi Menggunakan Metode Convolutional Neural Network”, dibuat sebuah sistem analisa akurasi performa pengenalan tulisan tangan angka menggunakan metode CNN (Convolutional Neural Network). Hasil yang didapat dari penelitian ini, bahwa performa neural network dipengaruhi oleh jumlah iterasi. Akurasi meningkat jika nilai iterasi dari 0-20, akan tetapi tidak ada pengaruh jika nilai iterasi dari 100-1000 [6].

Pada penelitian "Handwritten Digit Recognition using Convolutional Neural Network in Python with Tensorflow and Observe the Variation of Accuracies for Various Hidden Layers", hasil yang didapat variasi tulisan tangan diamati dengan 15 epoch. Kurva akurasi dibuat untuk enam kasus dengan parameter yang berbeda menggunakan dataset digit CNN MNIST. Akurasi maksimum dan minimum diamati dengan hidden layer yang berbeda dengan batch size 100. Dari pengamatan tersebut akurasi kinerja maksimum didapat 99,21\% dengan 15 epoch dalam kasus kedua. Namun, akurasi minimum didapat sebesar 97,7\% pada kasus keenam [7].

Pada penelitian "Pengenalan Pola Tulisan Tangan Pada Formulir Perolehan Suara Pemilihan Presiden Dan Wakil Presiden Menggunakan Algoritma Principal Component Analysis”, Hasil yang didapatkan dari penelitian ini semakin banyak dan bervariasi citra data training maka semakin baik tingkat akurasi dari identifikasi yang dilakukan. Dimana hasil tingkat akurasi yang di dapat sebesar 28,94\% dari 340 data sampel uji citra formulir C1 PPWP dari 2040 karakter tulisan tangan. Algoritma Principal Component Analysis (PCA) mampu mengekstraksi nilai utama dari data citra tulisan tangan sebanyak 2040 dengan masing-masing data berukuran $56 \times 56$ pixel serta mampu melakukan identifikasi 6 karakter [8].

Oleh karena itu diusulkan satu pendekatan baru untuk mengurangi kesalahan dan tidak manual menggunakan pengenalan pola. Selanjutnya dilakukan proses prediksi pola angka dari lembar C1 baru dengan menggunakan sebuah metode. Beberapa metode telah digunakan untuk memprediksi pola angka yaitu, clonal selection, negative selection, immune network dan dendritic cell. Pada penelitian ini, metode yang digunakan Randomized Real-Valued Negative Selection Algorithm yang menggunakan pendekatan optimisasi Sistem Kekebalan Buatan (Artificial Immune System).

\section{METODOLOGI PENELITIAN}

\subsection{Tinjauan Pustaka}

Gonzalez dkk [9] mengusulkan sebuah algoritma baru yaitu Real-Valued Negative Selection Algorithm (RNSA) dimana algoritma ini berdasarkan heuristik untuk mendistribusikan detektor di non-self secara berurutan untuk memaksimalkan pencakupan. Algoritma ini menggunakan representasi bernilai nyata untuk self / non-self yang berbeda dari representasi biner yang digunakan dalam algoritma seleksi negatif [10].

Lalu Gonzalez dkk [11] mengusulkan algoritma Randomized Real-Valued Negative Selection (RRNS) yang dapat memberikan kriteria khusus untuk mengatur parameter algoritma dan untuk menilai kinerja yang diharapkan. Algoritma ini bertujuan untuk menghasilkan sekumpulan detektor hyperspherical yang mencakup ruang non-self. Algoritma ini terdiri dari dua Langkah, pertama, menghasilkan himpunan detektor awal. Kedua, mengoptimalkan distribusi himpunan untuk memaksimalkan cakupan non-self. Masukkan ke algoritma adalah sekumpulan sampel dari self set, $S^{\prime}$; variabilitas yang diizinkan dalam self set, $\mathrm{r}_{\text {self }}$; radius detektor, $\mathrm{r}_{\mathrm{ab}}$; dan kumpulan parameter $\prod$. 


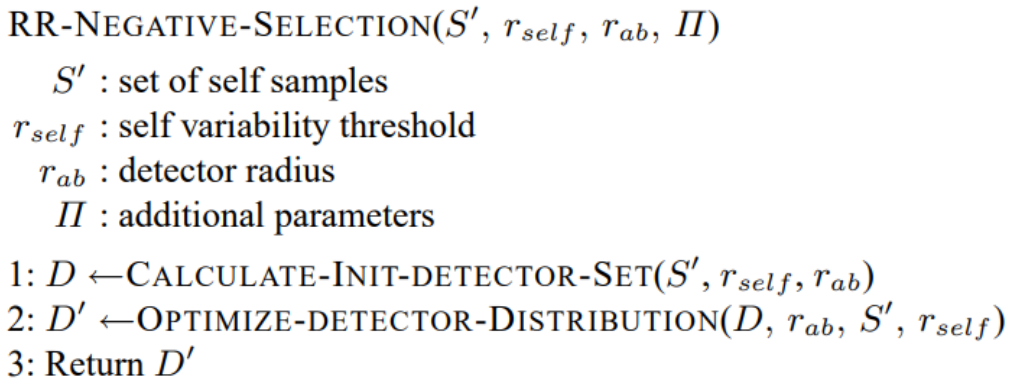

Gambar 1. Randomized Real-Valued Negative Selection Algorithm

(Sumber : semanticscholar, 2003)

Algoritma ini diimplementasikan dengan dua fungsi utama yaitu, calculate-init-detector-set yang memperkirakan volume ruang non-self untuk menghasilkan sekumpulan detektor awal yang baik dan optimizedetector-distribution yang mendistribusikan detektor secara seragam pada non-self berdasarkan annealing optimization.

\subsubsection{Menentukan Jumlah Detektor}

Misal $V_{d}$ adalah volume dari detektor individu dan $V_{s}$ adalah volume dari non-self. Berikut persamaannya :

$$
\text { num }_{a b}=\frac{V_{\text {non-self }}}{V_{d}}
$$

Lalu mendefinisikan volume penutup sebagai volume hypercube. Alasan memilih definisi ini karena ada cara mudah untuk menutupi wilayah berdimensi-n menggunakan hypercube tanpa lubang. Volume yang ditutupi oleh detektor $d$ dengan radius $r$ didefinisikan sebagai berikut :

$$
V_{d}=\left(\frac{2 r}{\sqrt{n}}\right) n
$$

Dengan menggunakan persamaan (1) dan (2) memungkinkan untuk menghitung pendekatan yang baik dari jumlah detektor dengan radius tertentu untuk menutupi ruang non-self .

Menghitung volume himpunan self, ruang self / non-self, $U$, berdasarkan hypercube $[0,1]^{\mathrm{n}}$ yang berarti volume dari ruang self / non-self sama dengan 1.0. Volume dari ruang non-self didefinisikan sebagai berikut :

$$
V_{\text {non-self }}=1-V_{\text {self }}
$$

Asumsikan model dari self set, $\hat{S}$, didefinisikan kedalam himpunan self samples, $S^{\prime}$. Kedekatan ditentukan secara formal oleh ambang variabilitas $r_{\text {self }}$ yang mendefinisikan jarak minimum antara self sample dan elemen $x$, sehingga $x$ dapat dianggap sebagai bagian dari self set. Model self set, $\hat{S}$, didefinisikan sebagai berikut :

$$
\hat{S}:=\left\{x \in U \mid \exists_{S} \in S^{\prime},\|s-x\| \leq r_{\text {self }}\right\}
$$

Definisikan $V_{\text {self }}$ sebagai volume $S^{\prime}$, dihitung sebagai :

$$
V_{\hat{S}}:=\int_{U} x_{\hat{S}}(x) d x,
$$

Dimana $x_{\hat{S}}$ sesuai dengan fungsi karakteristik dari himpunan $\hat{S}$ yang ditentukan oleh

$$
x_{\hat{S}}(x):=\left\{\begin{array}{c}
1 \text { if } x \in \hat{S} \\
0 \text { if } x \notin \hat{S}
\end{array}\right.
$$

Dimungkinkan untuk menghasilkan perkiraan $V_{\hat{S}}$ menggunakan random sampling. Ide dasarnya untuk menghasilkan urutan $\left\{x_{i}\right\}_{i=1 . . m}$ sampel acak yang disebarkan secara seragam di $U$. Nilai yang diharapkan dari $x_{\hat{S}}\left(x_{i}\right)$ adalah

$$
E\left[x_{\hat{S}}\left(x_{i}\right)\right]=\int_{U} x_{\hat{S}}(x) d x=V_{\hat{S}} ;
$$

Oleh karena itu, perkiraan dari $E\left[x_{\hat{S}}\left(x_{i}\right)\right]$ juga merupakan perkiraan dari $V_{\hat{S}}$. Seperti diketahui, perkiraan yang baik dari mean variabel acak adalah mean dari kumpulan sampel. Jadi, kami menggunakan rata-rata $\left\{x_{\hat{S}}\left(x_{i}\right)\right\}_{i=1 . . m}$ sebagai perkiraan, $V_{\hat{S}}$ dari self volume :

$$
V_{\hat{S}} \approx \widehat{V_{\hat{S}}}=\frac{\sum_{i=1}^{m} x_{\hat{S}}\left(x_{i}\right)}{m}
$$

Perkiraan integral yang ditentukan dengan rata-rata satu set sampel acak dikenal sebagai integrasi Monte Carlo [12]. Keuntungan dari metode ini memungkinkan untuk menghitung interval untuk perkiraan integral. Dengan menggunakan central limit theorem [13] memungkinkan untuk menghitung interval sebagai :

$$
P_{r}\left(\left|\widehat{V}_{\hat{S}}-V_{\hat{S}}\right|<3 \sqrt{\frac{{\widehat{V_{\hat{S}}}}^{*}-{\widehat{V_{\hat{S}}}}^{2}}{m}}\right) \approx 0.998
$$


ISSN 2614-5278 (media cetak), ISSN 2548-8368 (media online)

Available Online at https://ejurnal.stmik-budidarma.ac.id/index.php/mib DOI 10.30865/mib.v5i3.2997

Dari persamaan di atas didapatlah sebuah algoritma untuk menghitung kumpulan detektor awal (gambar 2).

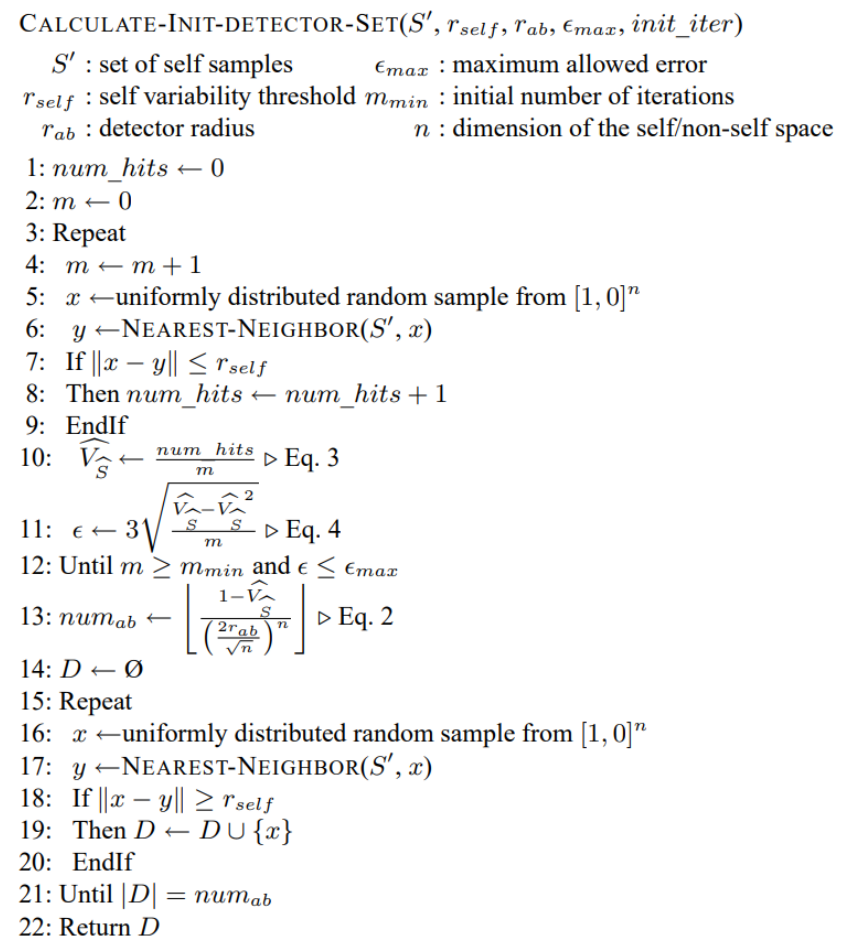

Gambar 2. Algoritma untuk Menghitung Kumpulan Detektor Awal (Sumber: semanticscholar, 2003)

\subsubsection{Meningkatkan Distribusi Detektor}

Algoritma untuk distribusi detektor dapat dilihat pada gambar 3. Masukkan utama pada algoritma ini adalah kumpulan detektor awal, $D$. Himpunan dari self samples $S^{\prime}$, dan jumlah iterasi num $_{\text {iter }}$. Bentuk detektor (self element) ditentukan oleh radius detektor, $r_{a b}$ dan ambang batas $s e l f r_{\text {self }}$. Jumlah iterasi pada perulangan dalam baris 5 hingga 20 diatur oleh parameter $\eta_{\text {min }}$, dimana dinyatakan sebagai jumlah minimum transisi yang diterima sebagai presentase dari jumlah detektor. Tingkat kerusakan suhu, $\alpha$, dan tingkat kerusakan lingkungan radius, $\alpha_{\text {pert }}$, mengontrol bagaimana suhu dan lingkungan radius akan berubah disetiap iterasi diluar pengulangan. Terakhir, parameter $\beta$ menentukan relatif dari menutupi self points ketika menghitung biaya.

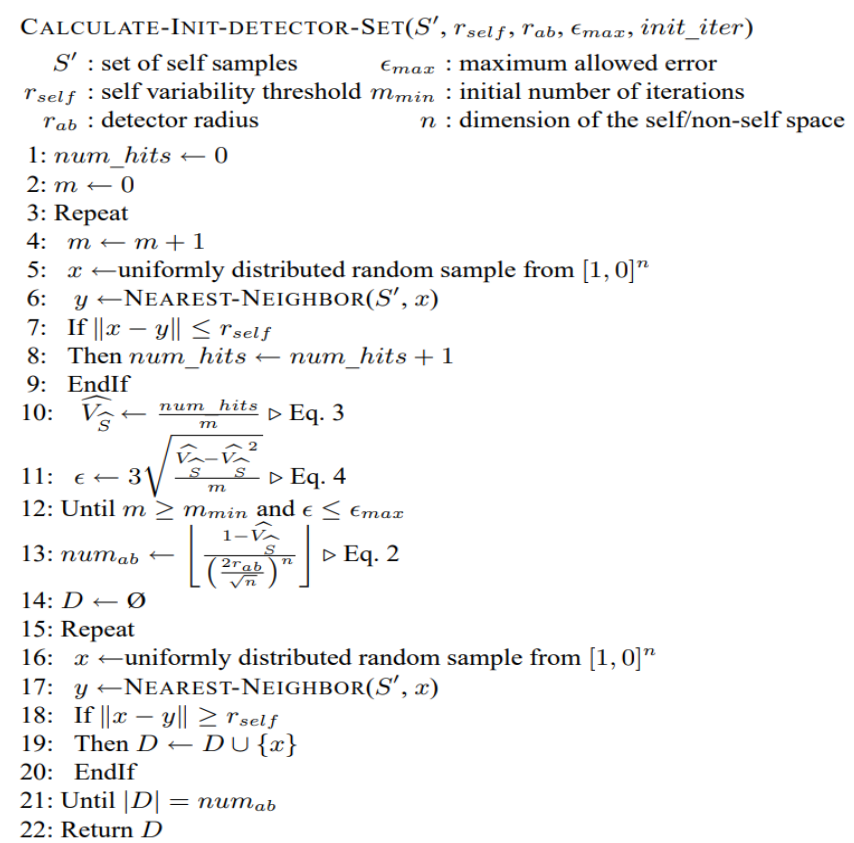

Gambar 3. Algoritma untuk Mengoptimalkan Distribusi Detektor (Sumber: semanticscholar, 2003) 
JURNAL MEDIA INFORMATIKA BUDIDARMA

Volume 5, Nomor 3, Juli 2021, Page 856-865

ISSN 2614-5278 (media cetak), ISSN 2548-8368 (media online)

Available Online at https://ejurnal.stmik-budidarma.ac.id/index.php/mib

DOI 10.30865/mib.v5i3.2997

\subsection{Tahap Penelitian}

Penelitian ini secara garis besar terdiri dari lima tahap, yaitu :

1. Mulai atau persiapan. Pada tahap persiapan penelitian, peneliti melakukan pengamatan (observasi) terlebih dahulu pada objek secara langsung yaitu dengan mencari data hasil perhitungan suara pemilu presiden dan wakil presiden Tahun 2019 berupa formulir model C1-PPWP di situs resmi KPU yaitu Situng (Sistem Informasi Penghitungan Suara). Data yang diamati hanya wilayah Penukal Abab Lematang Ilir Provinsi Sumatera Selatan.

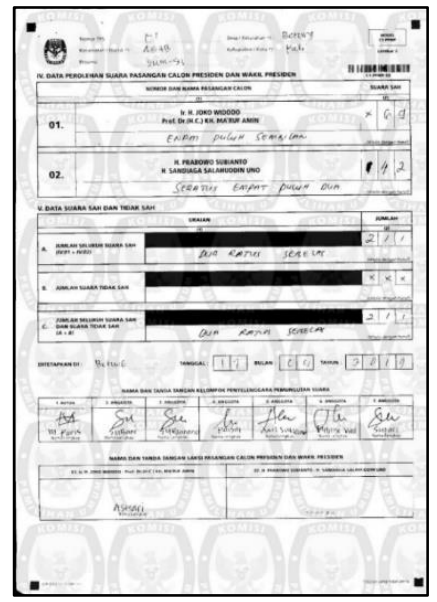

Gambar 4. Formulir C1

Setelah itu, peneliti mengumpulkan sebanyak 11 lembar dengan total data yang didapat sebanyak 528 data. Data ini dibuat dengan lembar C1 baru yang diusulkan.

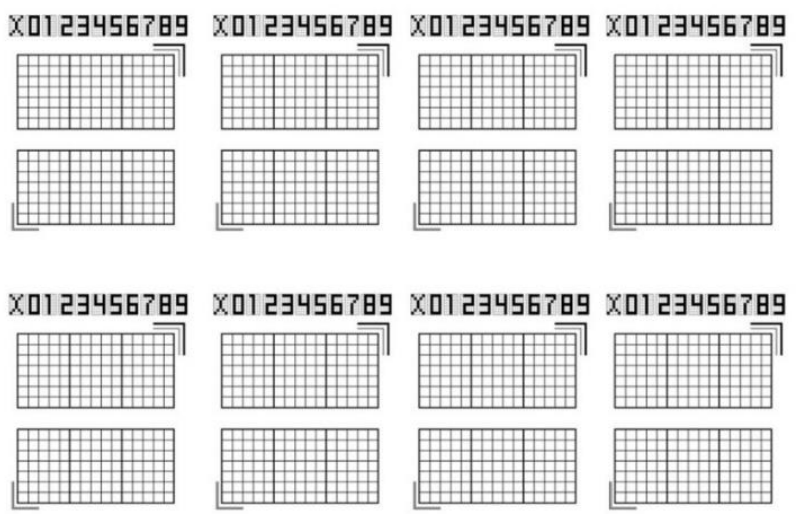

Gambar 5. Desain Lembar C1 yang diusulkan

Lalu peneliti mengarsir data dari angka 0 sampai 9 dan huruf $\mathrm{X}$ ke template lembar $\mathrm{C} 1$ yang diusulkan dengan cara diarsir menggunakan spidol berwarna, pena berwarna, pensil berwarna dan diwarnai menggunakan aplikasi pengolah gambar. Pola yang telah diarsir dengan spidol berwarna, pena berwarna dan pensil berwarna lalu discan (Gambar 6) dan di crop pada setiap box angka dan disimpan dalam bentuk format jpg (Gambar 7).

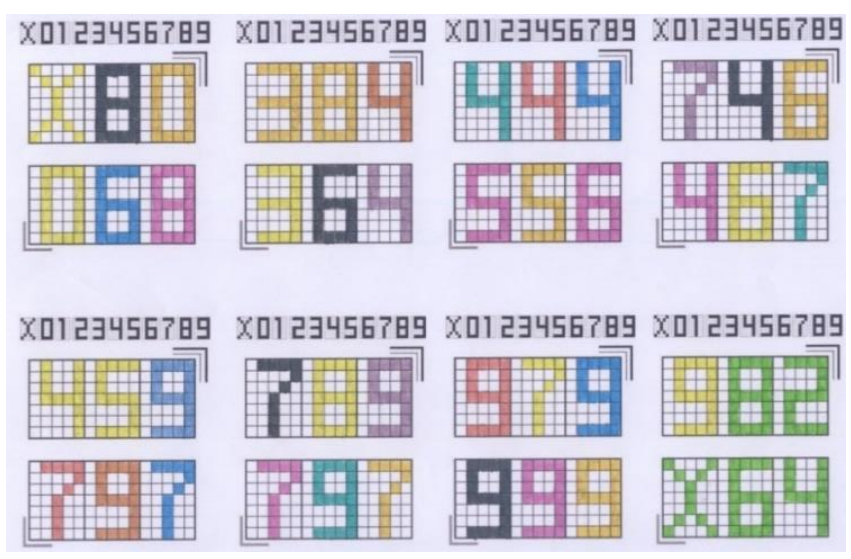

Gambar 6. Pola yang Telah diarsir

Anggari Ayu Prahartiningsyah, Copyright @2021, MIB, Page 860 Submitted: 30/04/2021; Accepted: 19/06/2021; Published: 31/07/2021 
ISSN 2614-5278 (media cetak), ISSN 2548-8368 (media online)

Available Online at https://ejurnal.stmik-budidarma.ac.id/index.php/mib DOI 10.30865/mib.v5i3.2997

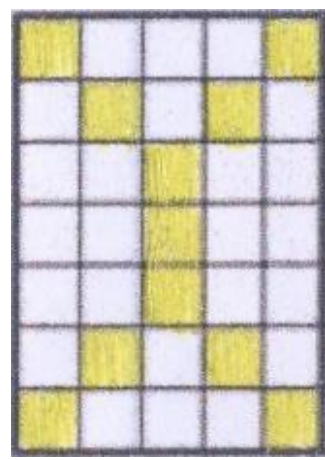

Gambar 7. Pola yang Telah di crop

2. Peneliti selanjutnya melakukan preprocessing data yang sudah dikumpulkan pada tahap pertama tadi. Proses data tersebut dilakukan untuk mengubah format warna yang tadinya full color menjadi grayscale dan mengubah ukurannya menjadi $15 \times 21$ pixel. Hasil pemrosesan tersebut akan disimpan dalam bentuk csv (comma separated values).

3. Selanjutnya data csv tersebut diproses menggunakan metode neural network untuk klasifikasi. Dimana klasifikasi ini akan menghasilkan berapa accuracy dan error yang didapat. Setelah itu, data diproses dan dimasukkan algoritma RRNS untuk mengetahui jumlah sample yang abnormal.

4. Hasil dan Pembahasan. Pada tahapan ini membahas mengenai hasil pengenalan pola angka dengan pendekatan Artificial Immune System dalam implemetasinya.

5. Kesimpulan. Tahapan ini, peneliti menarik kesimpulan dari hasil dan pembahasan yang telah dilakukan pada tahapan sebelumnya.

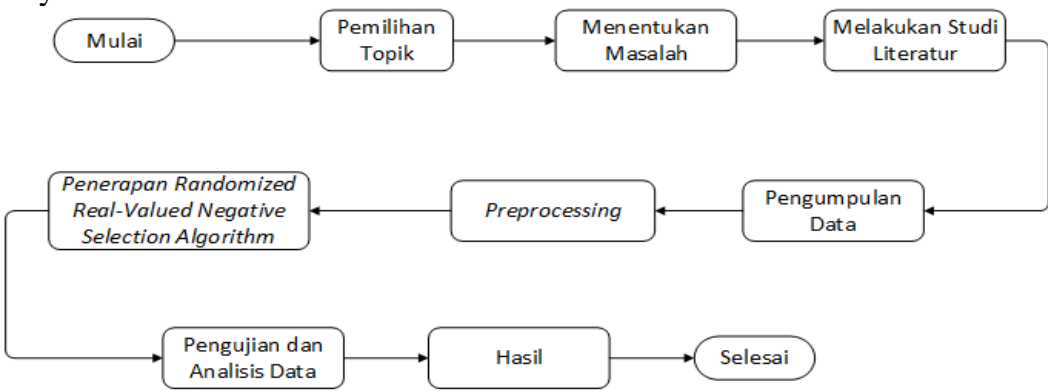

Gambar 8. Alur Penelitian

\subsection{Data Uji}

Data uji yang digunakan adalah data yang berupa angka 0 sampai 9 dan huruf $\mathrm{X}$ ke template lembar $\mathrm{C} 1$ yang diusulkan dengan cara diarsir menggunakan spidol berwarna, pena berwarna, pensil berwarna dan diwarnai menggunakan aplikasi pengolah gambar. Pola yang telah diarsir dengan spidol berwarna, pena berwarna dan pensil berwarna lalu discan dan di crop pada setiap box angka dan disimpan dalam bentuk format jpg. Data ini akan dibagi menjadi 2 yaitu data test dan data train dimana jumlah data test sebanyak 264 data dan data train sebanyak 264 data.
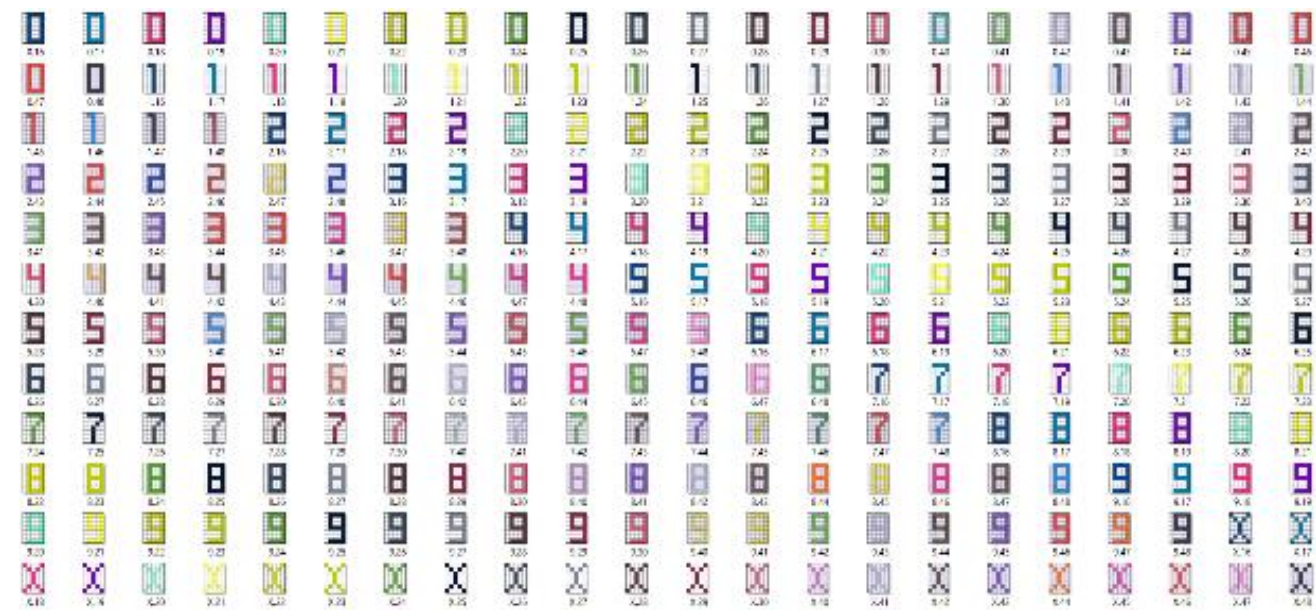

Gambar 9. Data Uji Test

Anggari Ayu Prahartiningsyah, Copyright (C2021, MIB, Page 861 Submitted: 30/04/2021; Accepted: 19/06/2021; Published: 31/07/2021 
JURNAL MEDIA INFORMATIKA BUDIDARMA

Volume 5, Nomor 3, Juli 2021, Page 856-865

ISSN 2614-5278 (media cetak), ISSN 2548-8368 (media online)

Available Online at https://ejurnal.stmik-budidarma.ac.id/index.php/mib DOI 10.30865/mib.v5i3.2997
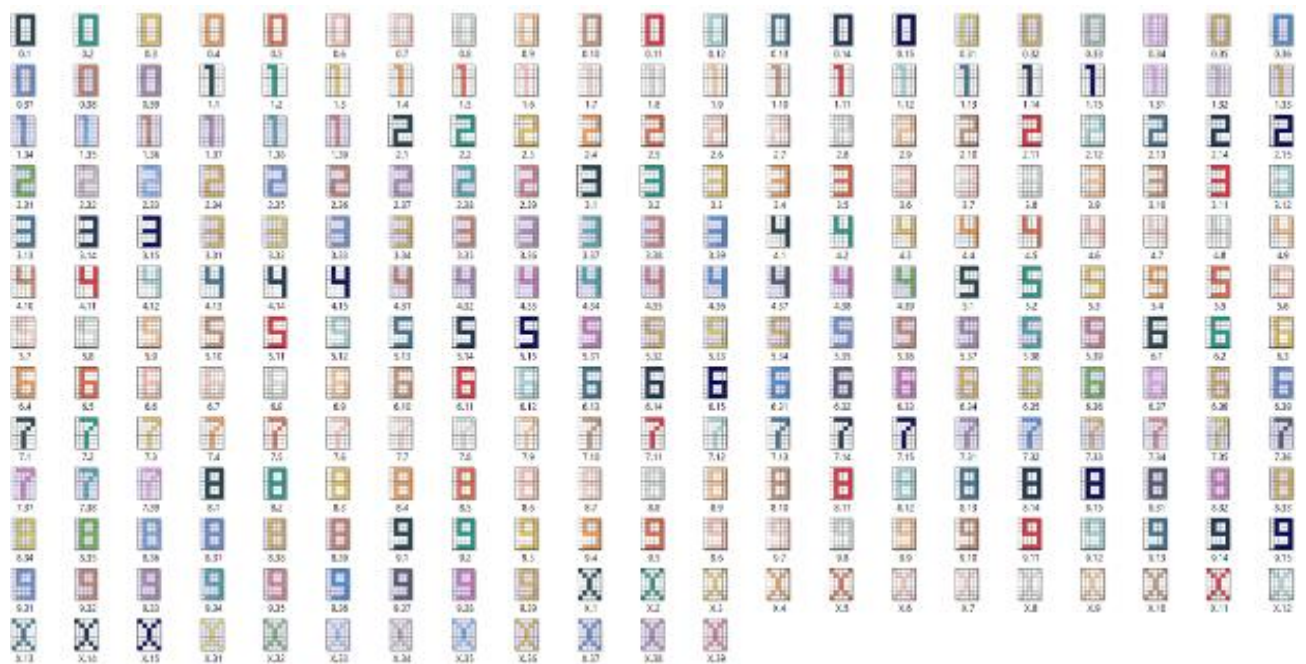

Gambar 10. Data Uji Train

\subsection{Preprocessing}

Data yang telah dibagi selanjutnya akan dilakukan preprocessing. Tujuan dilakukannya preprocessing adalah untuk mengubah ukuran gambar menjadi 15x21 pixel dan warna gambar menjadi grayscale. Lalu data tesebut disimpan dengan format file csv.

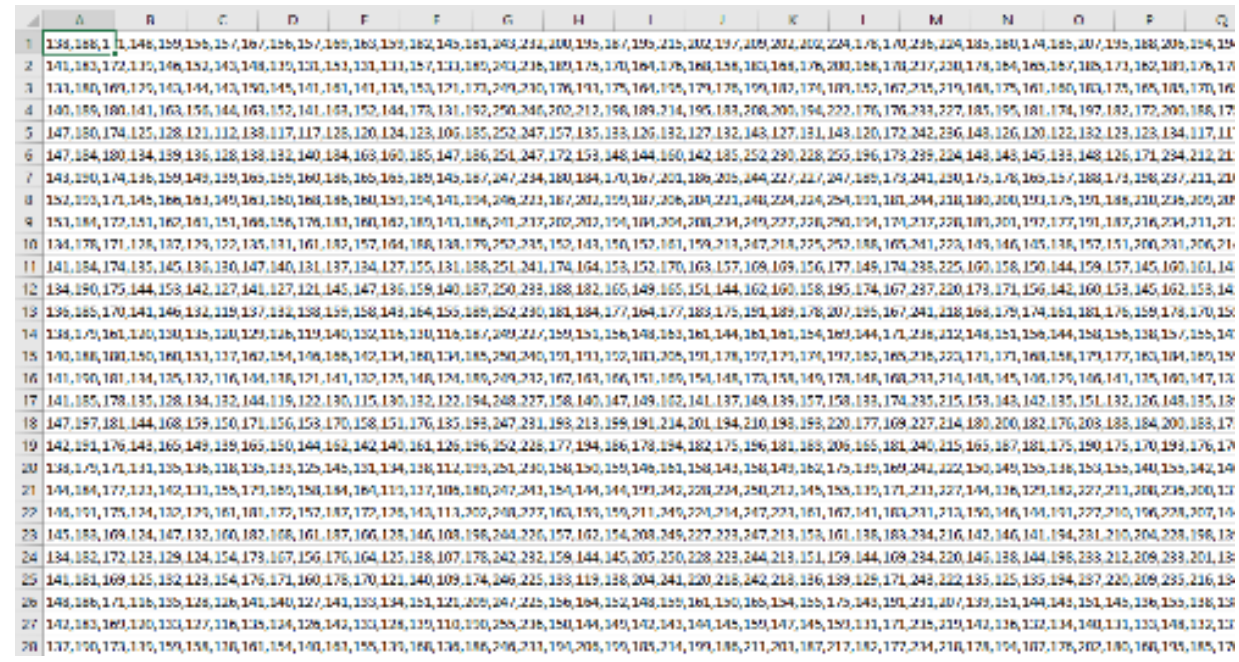

Gambar 11. Data Test

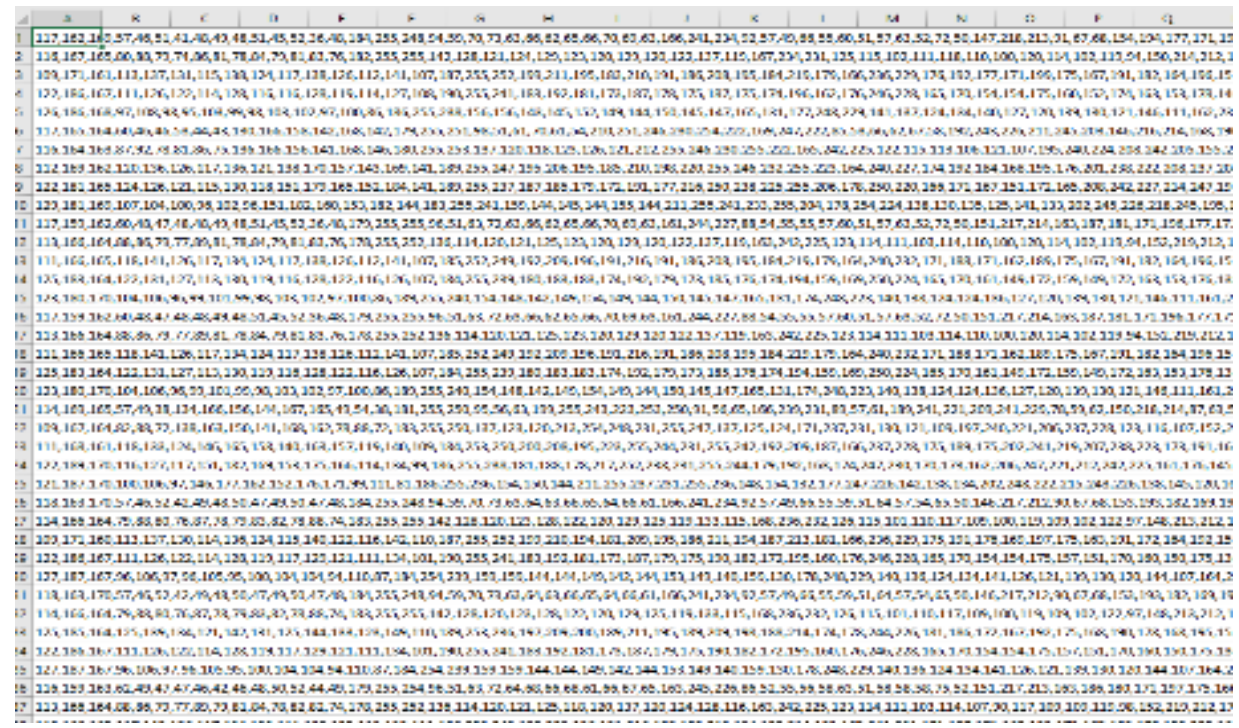

Gambar 12. Data Train

Anggari Ayu Prahartiningsyah, Copyright (C2021, MIB, Page 862 


\section{HASIL DAN PEMBAHASAN}

\subsection{Preprocessing}

Pada tahap ini dilakukan preprocessing dataset, dimana dataset diproses untuk mengubah ukuran gambar menjadi 15x21 pixel dan warna gambar menjadi grayscale. Lalu disimpan kedalam bentuk file csv.

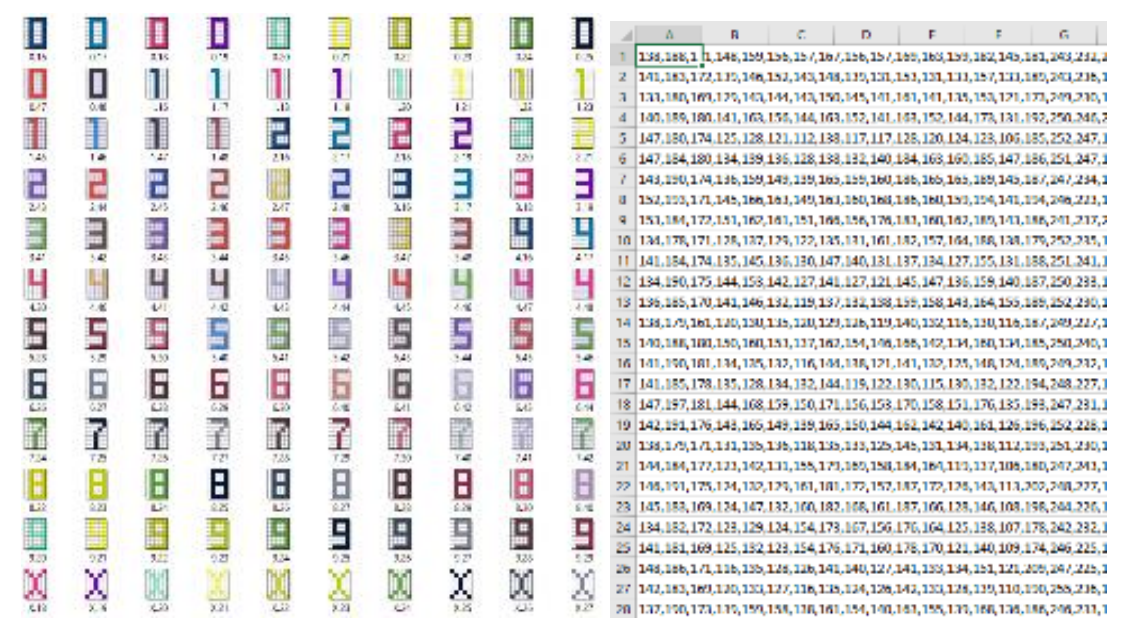

Gambar 13. Data Preprocessing

\subsection{Klasifikasi}

Proses klasifikasi bertujuan untuk mengetahui akurasi dan eror yang didapat dengan melakukan pengulangan pengujian sebanyak 15 kali. Data yang di proses adalah data Test dan data Train dalam bentuk file csv.

\subsection{Randomized Real-Valued Negative Selection Algorithm}

Pada pengujian ini diukur dari hasil calculate-init-detector-set dan optimize-detector-distribution. Dimana tujuannya untuk mendapatkan hasil detektor yang baik. Data yang di proses adalah data Test dan data Train dalam bentuk file csv.

\subsection{Hasil Pengujian Sistem}

Berikut hasil pengujian sistem.

\subsubsection{Hasil Klasifikasi}

Pada pengujian ini peneliti memasukkan nilai iterasi 15 dan nilai node hidden $\left(\mathrm{n} \_\mathrm{h}\right)=5$ dan akan diulang sebanyak 15 kali dengan rumus $\mathrm{n} \_\mathrm{h}=\mathrm{n} \_\mathrm{h}+10$, hasil yang didapat untuk Testing Accuracy: 85.85715728861501 sedangkan untuk Testing Error : 0.14142842711384984 . Nilai untuk train accuracies dan test accuracies serta grafik sebagai berikut :

Tabel 1. Train Accuracies and Test Accuracies

\begin{tabular}{ccc}
\hline Range & Train Accuracies & Test Accuracies \\
\hline 0 & 0 & 0 \\
1 & 100.0 & 98.98979694918678 \\
2 & 100.0 & 68.91605212647742 \\
3 & 100.0 & 60.09697949287806 \\
4 & 100.0 & 100.0 \\
5 & 100.0 & 100.0 \\
6 & 100.0 & 100.0 \\
7 & 100.0 & 100.0 \\
8 & 100.0 & 99.4948984745934 \\
9 & 100.0 & 100.0 \\
10 & 100.0 & 100.0 \\
\hline
\end{tabular}


ISSN 2614-5278 (media cetak), ISSN 2548-8368 (media online)

Available Online at https://ejurnal.stmik-budidarma.ac.id/index.php/mib DOI 10.30865/mib.v5i3.2997

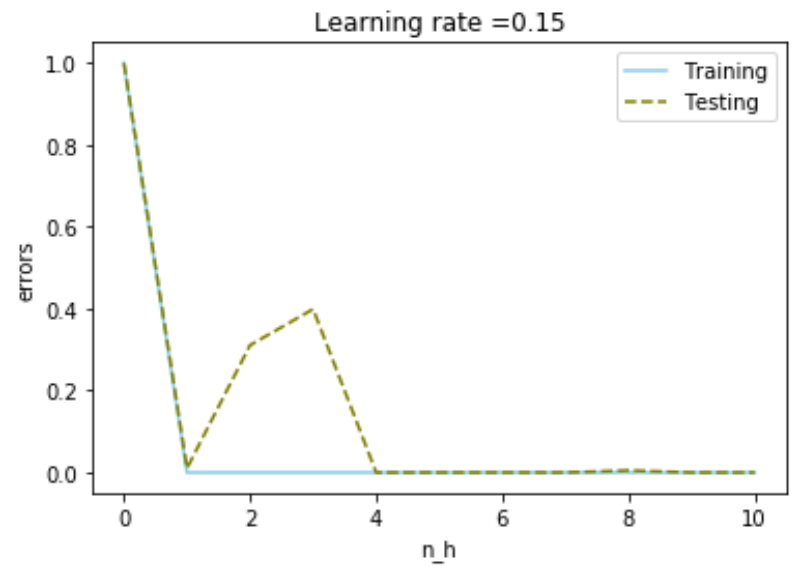

Gambar 14. Grafik Nilai Train Accuracies dan Test Accuracies

\subsubsection{Hasil Algoritma RRNS}

Pada pengujian ini diukur dari hasil calculate-init-detector-set dan optimize-detector-distribution. Sehingga didapatkan hasil sebagai berikut.

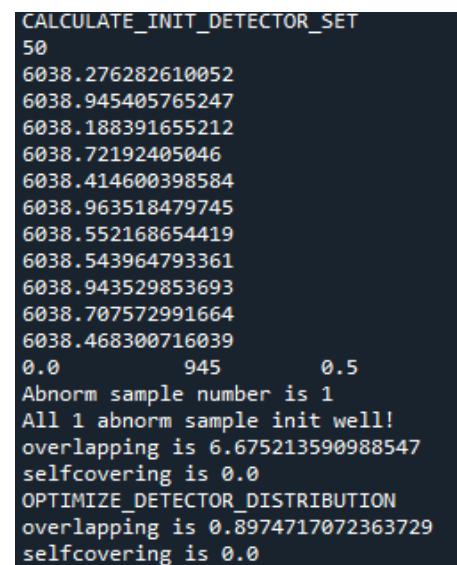

Gambar 15. Hasil Pengujian RRNS

Berdasarkan gambar diatas dapat dijelaskan untuk iterasi bernilai 10 didapatkan hasil untuk pengujian calculate init detector set nilai overlapping bernilai 6.675213590988547. Sedangkan untuk selfcovering bernilai 0.0. Lalu pada pengujian optimize detector distribution nilai overlapping bernilai 0.8974717072363729 , sedangkan untuk selfcovering tetap bernilai 0.0 .

\section{KESIMPULAN}

Berdasarkan hasil penelitian yang telah dilakukan dapat ditarik kesimpulan bahwa implementasi dengan menggunakan metode Randomized Real-Valued Negative Selection Algorithm lebih baik dalam menganalisis proses kinerjanya. Semakin banyak data maka akan semakin baik tingkat akurasi yang didapat.

\section{UCAPAN TERIMAKASIH}

Terima kasih kepada suami ku tercinta yang telah memberi semangat, doa dan dukungan dalam menyelesaikan penelitian ini. Terima kasih juga kepada Dosen Pembimbing, Dosen Penguji, teman-teman dan seluruh pihak yang tidak bisa disebutkan satu per satu.

\section{REFERENCES}

[1] Primartha, Rifkie, "Belajar Machine Learning", Penerbit Informatika, 2018

[2] Dasgupta, D., \& Niño, L. F., "Immunological Computation". Washington: Auerbach Publications, 2009.

[3] Zulkarnaen, Iskandar, "Gunakan Aplikasi agar Salah Input Tidak Jadi Tragedi". 2019.

[4] Jérǒme, H. and Carter, "The Immune System as a Model for Pattern Recognition and Classification", Journal of the American Medical Informatics Association Volume 7 Number 1, 1999. 
ISSN 2614-5278 (media cetak), ISSN 2548-8368 (media online)

Available Online at https://ejurnal.stmik-budidarma.ac.id/index.php/mib DOI 10.30865/mib.v5i3.2997

[5] Igawa K. and Ohashi H., "A Negative Selection Algorithm for Classification and Reduction of the Noise Effect”. Appl. Soft Comput. J., 2008.

[6] Prihatiningsih, Siwi \& M, Nadhiranisa \& Andriani, Feni \& Nugraha, Nurma, "Analisa Performa Pengenalan Tulisan Tangan Angka Berdasarkan Jumlah Iterasi Menggunakan Metode Convolutional Neural Network". Jurnal Ilmiah Teknologi dan Rekayasa, 2019.

[7] Siddique, F.; Sakib, S.; Siddique, M.A.B., "Handwritten Digit Recognition using Convolutional Neural Network in Python with Tensorflow and Observe the Variation of Accuracies for Various Hidden Layers", 2019.

[8] Wardani, Aditia., Syaripudin, Undang., Budiawan Zulfikar, Wilda., Lukman, Nur., "Pengenalan Pola Tulisan Tangan Pada Formulir Perolehan Suara Pemilihan Presiden Dan Wakil Presiden Menggunakan Algoritma Principal Component Analysis", 2020.

[9] Gonzalez, F., Dasgupta, D., Kozma, R., "Combining Negative Selection and Classification Techniques for Anomaly Detection", Volume 1, Congress on Evolutionary Computation. Honolulu, Hawaii. May, 2002. pp705-710, 2002.

[10] Forrest, S., Perelson, A., Allen, L., R., and Cherukuri, "Self-Nonself Discrimination In a Computer". In Proceedings of the 1994 IEEE Symposium on Research in Security and Privacy, pages 202-212, Los Alamitos, CA. IEEE Computer Society Press, 1994

[11] Gonzalez, F., D. Dasgupta, L. F. Nino, “A Randomized Rea-Valued Negative Selection Algorithm”, $2^{\text {nd }}$ International Conference on Artificial Immune System (ICARIS), UK, 2003.

[12] J. S. Liu., "Monte Carlo Strategies in Scientific Computing". Springer-Verlag, 2001.

[13] H. D. Brunk, "An Introduction to Mathematical Statistics". Blaisdell Publishing Co., 1965.

[14] Dasgupta, D., “Advances in Artificial Immune Systems”. IEEE Computational Intelligence Magazine, 2006.

[15] De Castro, Leandro \& Timmis, Jon, "Artificial immune system: A novel paradigm to pattern recognition". ANNIS. 8, 2002.

[16] Jannakha Putra, Benny., Basuki Kurniawan, Tri., Antoni, Darius., Haidar Mirza, Ahmad., "Prediksi Kebutuhan Alat Kesehatan Rumah Sakit Menggunakan Metode Algoritma Regression Linier dan Naïve Bayes", Jurnal Ilmiah Informatika Global Volume 11 No. 2 Desember 2020, 2020.

[17] Zaliman, Iski., Basuki Kurniawan, Tri., Antoni, Darius., "Sistem Penentuan Lokasi Pusat Layanan Terpadu Bagi Penderita Penyakit Demam Berdarah Dengan Menggunakan K-Means Clustering”, Jurnal Ilmiah Informatika Global Volume 11 No. 2 Desember 2020, 2020.

[18] Igawa K. and Ohashi H., "A Negative Selection Algorithm for Classification and Reduction of the Noise Effect". Appl. Soft Comput. J. (2008), DOI:10.1016/j.asoc.2008.05.003, 2008.

[19] Al-Enezi, J.R., Abbod, M.F. and Al-Sharhan, Salah, "Artificial Immune Systems-Models, Algorithms and Applications". International Journal of Research and Reviews in Applied Sciences. 3, 2010. 